\title{
ANALISA PERANCANGAN ULANG (REDESAIN) MODEL OPERASIONALISASI PROGRAM BANTUAN OPERASIONAL SEKOLAH DALAM MENINGKATKAN EFEKTIVITAS PENYELENGGARAAN PENDIDIKAN DAN MEMENUHI HARAPAN MASYARAKAT
}

\author{
Hesti Maheswari (Universitas Mercu Buana) \\ Luna Haningsih (Universitas Mercu Buana) \\ hesti.maheswari@gmail.com
}

\begin{abstract}
This study aims to establish a model operationalization BOS program, through the analysis of Quality Function Deployment. This study was based on the presence of a variety of complaints that come from the communities to the BOS program that they can not benefit from the one hand, and the other side the Government felt that the implementation of BOS has reached three rights are the right time, the right amount, and on target. Public dissatisfaction conditions to the program evidenced by the high dropout rates. The extent to which the BOS program helps students in education funding, in turn raises a big question mark because of government policies and rhetoric seem apparent.Because it was the children of farmers, laborers, street vendors, low class servants, janitors still do not get the ease and lightness in education.Free school which echoed the Government would make society under increasingly sad to hear that.
\end{abstract}

The first results of this study is the expectationof the people to the BOS program, namely:most of BOS funds can be used to offset the cost of student transportation, schools have adequate science laboratories and maximum usage, quality textbooks provided by the school, BOS program can ease the burden of school, students can discuss with the teacher outside of school hours, andSchool Committee oversees use of the funds. From this analysis known gap formed between community expectations with the level of BOS concept is still very high, both western and central regions Indonesia.Researchers feel that there is no proper policy of the Government to secure the nation's ideals in improving quality through Learning Program 9 years.Therefore, we need strategies to be more comprehensive to narrow the gap between idealism with the realities on the ground, so that education becomes more obvious problems 'roots' and more 'effective and efficient' ways to overcome. Redesigns recommended are monitoring and evaluation, increase teacher motivation, integrated management system, operational guidelines for use of the funds, supervision attached, and additional facilities. To accomplish these results it is necessary to continue the research terms, that is for two eastern Indonesia: Maluku and Papua.

Keywords: recommendation of operationalization model BOS program, quality function deployment 


\section{PENDAHULUAN}

Keinginan pemerintah untuk meningkatkan kualitas SDM melalui pendidikan dapat kita lihat salah satunya melalui pemberlakuan wajib belajar (wajar) 9 tahun. Dengan program ini diharapkan tidak akan ada SDM bangsa yang tidak berpendidikan di tanah air, minimal pendidikan dasar. Pemerintah menargetkan program ini tuntas tahun depan. Hal ini didukung dengan Undang-undang No. 20 Tahun 2003 tentang Sistem Pendidikan Nasional yang mengamanatkan bahwa setiap warga negara yang berusia 7-15 tahun wajib mengikuti pendidikan dasar. Pasal 34 ayat 2 menyebutkan bahwa Pemerintah dan Pemerintah Daerah menjamin terselenggaranya wajib belajar minimal pada jenjang pendidikan dasar tanpa memungut biaya, sedangkan dalam ayat 3 menyebutkan bahwa wajib belajar merupakan tanggung jawab negara yang diselenggarakan oleh lembaga pendidikan pemerintah, pemerintah daerah dan masyarakat. Secara umum Program BOS bertujuan untuk meringankan beban masyarakat terhadap pembiayaan pendidikan dalam rangka wajar 9 tahun yang bermutu. Secara khusus program BOS bertujuan untuk: 1) Menggratiskan seluruh siswa miskin di tingkat pendidikan dasar dari beban biaya operasional sekolah, baik di sekolah negeri maupun sekolah swasta; 2) Menggratiskan seluruh siswa SD dan SMP negeri terhadap biaya operasional sekolah, kecuali pada rintisan sekolah bertaraf internasional dan sekolah bertaraf internasional; 3) Meringankan beban biaya operasional sekolah bagi siswa di sekolah swasta.

Faktanya di lapangan, terlihat strategi ini tampaknya masih menghadapi persoalan.Salah satunya, kenaikan biaya pendidikan yang terkesan tidak terkendali, yaitu ada pembebasan biaya disatu komponen semisal SPP, namun banyak komponen lain yang harus dibayar dalam jumlah yang tidak murah,misalnya, pakaian seragam, uang pangkal, biaya ulangan umum atau ujian, dan lainnya, sehingga, terutama bagi masyarakat miskin, memenuhi standar pendidikan wajar 9 tahun bukan persoalan mudah. Keterpurukan ekonomi tidak boleh dijadikan alasan pemerintah untuk membiarkan biaya pendidikan menjadi tidak terkendali seperti saat ini, setidaknya strategi ini harus diamankan untuk wajar 9 tahun. Angka partisipasi murni SD saat ini sudah mencapai 90 persen lebih, sedangkan SMP di angka 60-an persen dengan kecenderungan membaik setiap tahun. Namun, jumlah anak putus sekolah SD setiap tahun rata-rata berjumlah 600.000 hingga 700.000 siswa.Sementara itu, jumlah mereka yang tidak menyelesaikan sekolahnya di SMP sekitar 150.000 sampai 200.000 orang (Litbang Kompas, Januari 2009).Tidak ada yang salah dengan ProgramBOS, hanya saja perlu dipahami, bahwa pertama;persepsi masyarakat yang berbeda tentang BOS dan harus secepatnya diluruskan.Masyarakat berpikir bahwa dengan adanya BOS, biaya sekolah benar-benar gratis seratus persen. Kedua,para pelaksana di lapangan sengajamemperbesarRencana Anggaran dan Pendapatan Belanja Sekolah, sehingga mereka mempunyai alasan untuk tetap memungut sejumlah dana.

Tujuan mulia saja dari program BOS tidak cukup untuk menjadikannya sebuah kebijakan yang baik.Pada kenyataannya, BOS dikelilingi beberapa persoalan yang jika tidak diatasi secara arif berpotensi mengurangi keberhasilan pencapaian tujuan mulia tersebut.Masalah utama terkait dengan program BOS sebenarnya terletak pada pengendalian dan pengawasannya.Ada dua level pengawasan yang diperlukan, yakni pengawasan penggunaan dana BOS dan pengawasan terhadap efektivitas program BOS. Idealnya, komite sekolah sebagai representasi masyarakat/orangtua diberi otoritas untuk mengawasi penggunaan BOS 
di sekolah.Pemerintah perlu pula mengawasi apakah mekanisme pengawasan oleh komite sekolah berjalan, atau justru terjadi kolusi di antara keduanya. Sejauh mana efektivitas program BOS membantu siswa dalam pembiayaan pendidikan begitu juga bantuan-bantuan pembiayaan lainnya, pada akhirnya menimbulkan tanda tanya besar. Dalam upaya memaksimalkan manfaat Program BOS maka sebaiknya ada pihak yang aktif mengevaluasi pelaksanaan BOS dengan melihat langsung pada fenomena yang ada dilapangan yaitu pada masyarakat yang menikmati dana BOS.

Oleh karena itu, penelitian ini mempunyai tujuan khusus, yaitu :

1. Mendapatkan gambaran harapan masyarakat terhadap program BOS. Dalam hal ini peneliti ingin mendapatkan gambaran secara komprehensif tentang harapan, persepsi dan pandangan masyarakat terhadap Program BOS, sehingga Pemerintah dapat merealisasikannya.

2. Mendapatkan gambaran kepuasan masyarakat terhadap Program BOS. Seberapa jauh mereka merasa terbantu dalam membiayai sekolah anak-anaknya dengan adanya program ini.

3. Mendapatkan gambaran karakteristik teknis dari Program BOS yang sebenarnya. Definisi, batasan, ruang lingkup dan model Program BOS, sehingga masyarakat dapat mengetahui dengan tepat dan jelas maksud dan tujuan dengan adanya Program BOS.

4. Mendapatkan gambaran antara idealisme pemerintah dalam tataran 'konsep' dan 'realitas pelaksanaan' Program BOS di lapangan, sehingga dapat diketahui seberapa jauh Program BOS ini sudah benar-benar tepat sasaran dan dirasakan manfaatnya oleh seluruh anak bangsa, sesuai visi, misi dan tujuannya.

5. Merumuskan modeloperasionalisasi dan kebijakan-kebijakan yang harus dilakukan oleh Pemerintah, agar tujuan Program BOS tercapai sesuai diamantkan dalam UU No. 20 ayat 2 dan 3.

\section{KAJIAN PUSTAKA}

BOS adalah program pemerintah untuk penyediaan pendanaan biaya nonpersonalia bagi satuan pendidikan dasar sebagai pelaksana program wajib belajar. Indikator utama efektivitas pelaksanaan Program BOS adalah (1) mayoritas anak usia pendidikan dasar bersekolah APM $>95 \%$, (2) berkurangnya Angka Putus Sekolah, dan (3) berkurangnya beban orangtua untuk menyekolahkan anaknya di pendidikan dasar. Untuk kepentingan ini Pemerintah sebagai pemilik program harus mengkaji, mengawasi, termasuk mengendalikan pelaksanaan programnya. Proses pengawasan yang paling mudah adalah dengan mengetahui kepuasan masyarakat terhadap program ini. Informasi ini kemudian dipadukan dalam desain Program BOS, bagaimana agar tiap area fungsional dapat memahami dan melaksanakannya. Dengan matriks house of quality (metode QFD), kita dapat mengetahui seberapa besar gap atau penyimpangan dari apa yang diharapkan dengan apa yang dirasakan oleh masyarakat. Dari matriks ini kita dapat melihat apakah karakteristik yang menjadi keunggulan sebuah Program

BOS telah dapat memuaskan masyarakat sesuai dengan tujuan Program BOS.Pada tahap 
pertama penelitian, analisis dilakukan hingga ruang 3 bagan house of quality, yang menggambarkan harapan masyarakat terhadap program BOS, kepuasan masyarakat terhadap program tersebut, dan karakteristik teknis program BOS. Pada tahap kedua penelitian, penelitian akan dilanjutkan 3 langkah lagi, yaitu: 1) menganalisis hubungan harapan masyarakat terhadap program BOS dengan karakteristik teknis yaitu keunggulan dari program BOS yang memang Pemerintah Indonesia berikan untuk masyarakat. 2) Menghubungkan masing-masing karakteristik teknis untuk kepentingan perbaikan karakteristik yang satu dengan karakteristik lainnya. 3) Menentukan karakteristik teknis yang harus didesain ulang karena tidak sesuai dengan harapan masyarakat, yang kemudian akan diusulkan sebagai perbaikan pelaksanaan program BOS.

\section{PEMBAHASAN}

\section{Harapan dan Persepsi Masyarakat Terhadap Program BOS}

Dari hasil telaah terhadap kuesioner terbuka maka ditemukanrata-rata kebutuhan masyarakat terhadap sekolah yang nota bene memperoleh dana BOS untuk ketiga wilayah Indonesia, yaitu : 1) Murid mendapat kursi dan meja belajar; 2) Sirkulasi udara di ruang kelas baik; 3) Taman sekolah sebagai paru-paru sekolah; 4) Terdapat peralatan laboratorium IPA; 5) Sarana olahraga; 6) Buku-buku pelajaran tersedia; 7) Sanitary sekolah bersih; 8) Tulisan pada papan tulis terbaca; 9) Siswa berseragam dengan baik; 10) Masyarakat tidak dipungut uang pangkal/uang gedung; 11)Sekolah bebas dari iuran bulanan; 12) Kegiatan ekstra kurikuler tidak dipungut biaya; 13) Sekolah bebas biaya UTS; 14) Bebas biaya UAS; 15) Buku-buku dipinjamkan; 16) Lembar kerja siswa (LKS) diberikan cuma-cuma; 17) Program BOS meringankan beban biaya sekolah; 18) Pembebanan biaya melihat kemampuan keuangan masing-masing; 19) Kegiatan belajar mengajar sesuai dengan kalender akademik; 20) Sekolah tidak pernah memulangkan siswa lebih cepat dari jadwalnya; 21) Guru menguasi materi pelajaran; 22) Kemauan mengajar guru; 23) Guru banyak memberikan soal-soal latihan; 24) Guru membahas seluruh soal yang diberikan; 25) Guru seorang sarjana pendidikan; 26) Guru mengenal baik setiap siswa; 27) Siswa dapat berdiskusi dengan gurunya di luar jam belajar; 28) Materi yang disampaikan sesuai dengan satuan acara pelajaran/silabi; 29) Guru mengajar hingga siswa paham; 30) Guru membahas seluruh soal latihan yang diberikan; 31) Kurikulum sekolah sesuai dengan kurikulum pemerintah; 32) Guru memberikan pendalaman materi kepada siswa; 33) Program BOS meringankan beban biaya sekolah; 34) Sebagian dana BOS digunakan untuk meringankan biaya transportasi siswa ke sekolah; 35) Tidak ada pungutan sekolah yang harus dibayar; 36) Orang tua terlibatdalam penyusunan RAPBS; 37) Orang tua terlibat dalam pengawasan penggunaan dana BOS; 38) Komite sekolah mengawasi penggunaan dana BOS; dan 39) Kegiatan ekstra kurikuler terlaksana dengan baik

\section{Gambaran Kepuasan Masyarakat Terhadap Program BOS}

Populasi pada penelitian ini adalah Orang tua siswa dan siswa SDN dan SMPN di seluruh Indonesia yang terbagi dalam wilayah Indonesia Barat, Indonesia Tengah, dan Indonesia Timur dengan teknik penarikan sampel yaitu dengan metode convenience sampling. Dari hasil uji validitas tingkat kepentingan dan kepuasan (SD) terdapat 8 dan 6 atribut invalid untuk digunakan sebagai alat ukur, sehingga tidak dapat dijadikan instrumen dalam penelitian ini. Sedangkan untuk hasil uji validitas tingkat kepentingan dan kepuasan (SMP), terdapat 9 dan 2 
atribut yang tidak valid. Hasil pengujian reliabilitas instrument, instrumen penelitian reliable untuk kedua jenis sekolah.

Tabel 1.Analisa GAP Kepuasan Masyarakat SD Terhadap Program BOS

\begin{tabular}{|c|c|c|c|c|}
\hline $\begin{array}{l}\mathrm{N} \\
\mathrm{O}\end{array}$ & Atribut Pelayanan & $\begin{array}{c}\text { GAP } \\
\text { IB }\end{array}$ & $\begin{array}{l}\text { GAP } \\
\text { IT }\end{array}$ & $\begin{array}{l}\text { GAP } \\
\text { KB }\end{array}$ \\
\hline 1 & Sirkulasi udara di ruang kelas baik & $-1,4$ & $-0,3$ & $-1,3$ \\
\hline 2 & Sekolah memiliki peralatan laboratorium IPA & $-2,7$ & $-3,2$ & $-2,0$ \\
\hline 3 & Buku-buku pelajaran disediakan oleh sekolah & $-2,6$ & $-2,8$ & $-1,7$ \\
\hline 4 & Sanitary sekolah bersih & $-1,6$ & $-0,7$ & $-0,8$ \\
\hline 5 & $\begin{array}{l}\text { Tulisan pada papan tulis dapat terbaca dari tempat duduk } \\
\text { siswa }\end{array}$ & $-2,2$ & $-1,6$ & $-2,0$ \\
\hline 6 & Siswa berseragam dengan baik & $-0,8$ & $-0,7$ & 0,2 \\
\hline 7 & Anda tidak dipungut uang pangkal/uang gedung oleh sekolah & $-1,9$ & $-0,6$ & 0 \\
\hline 8 & Sekolah bebas dari iuran bulanan seperti SPP atau BP3 & $-2,2$ & $-0,2$ & 0 \\
\hline 9 & Kegiatan ekstra kurikuler tidak dipungut biaya oleh sekolah & $-2,1$ & $-1,9$ & $-1,4$ \\
\hline $\begin{array}{l}1 \\
0\end{array}$ & Sekolah ini bebas biaya ulangan tengah semester & $-1,6$ & 0 & 0 \\
\hline $\begin{array}{l}1 \\
1\end{array}$ & Siswa dibebaskan dari biaya ulangan akhir semester & $-1,4$ & $-0,8$ & 0 \\
\hline $\begin{array}{l}1 \\
2\end{array}$ & Buku-buku dipinjamkan oleh sekolah kepada siswanya & $-1,2$ & $-2,8$ & $-0,3$ \\
\hline $\begin{array}{l}1 \\
3\end{array}$ & Lembar kerja siswa (LKS) diberikan cuma-Cuma & $-2,2$ & $-3,7$ & $-2,0$ \\
\hline $\begin{array}{l}1 \\
4\end{array}$ & $\begin{array}{l}\text { Program BOS meringankan beban biaya sekolah yang harus } \\
\text { Anda bayar }\end{array}$ & $-2,4$ & $-0,9$ & 0 \\
\hline $\begin{array}{l}1 \\
5\end{array}$ & $\begin{array}{l}\text { Pembebanan biaya dari sekolah tidak sama rata pada setiap } \\
\text { murid, namun melihat kemampuan keuangan masing-masing }\end{array}$ & $-2,4$ & $-1,8$ & $-2,0$ \\
\hline $\begin{array}{l}1 \\
6\end{array}$ & Guru menguasi materi pelajaran yang diberikan kepada siswa & $-2,2$ & $-1,2$ & $-1,9$ \\
\hline
\end{tabular}




\begin{tabular}{|c|c|c|c|c|}
\hline 17 & Guru mempunyai kemauan yang keras untuk mengajar & $-2,1$ & $-2,7$ & $-1,8$ \\
\hline 18 & Guru banyak memberikan soal-soal latihan & $-2,3$ & $-2,8$ & $-1,4$ \\
\hline 19 & Guru membahas seluruh soal yang diberikan & $-2,2$ & $-3,3$ & $-2,5$ \\
\hline 20 & $\begin{array}{l}\text { Siswa dapat berdiskusi materi pelajaran dengan gurunya di } \\
\text { luar jam belajar pada hari sekolah }\end{array}$ & $-2,5$ & $-2,2$ & $-1,4$ \\
\hline 21 & $\begin{array}{l}\text { Materi yang disampaikan sesuai dengan satuan acara } \\
\text { pelajaran/silabi }\end{array}$ & $-2,2$ & $-0,4$ & $-1,0$ \\
\hline 22 & Guru mengajar hingga siswa paham & $-2,3$ & $-2,7$ & $-1,4$ \\
\hline 23 & $\begin{array}{l}\text { Guru memberikan pendalaman materi kepada siswa yang } \\
\text { terlambat dalam menyerap materi }\end{array}$ & $-2,3$ & $-3,7$ & $-0,4$ \\
\hline 24 & Program BOS meringankan beban biaya sekolah anak Anda & $-2,6$ & $-1,4$ & 0 \\
\hline 25 & $\begin{array}{l}\text { Sebagian dana BOS digunakan untuk meringankan biaya } \\
\text { transportasi siswa ke sekolah }\end{array}$ & $-2,8$ & $-3,1$ & $-2,3$ \\
\hline 26 & Orang tua terlibat dalam penyusunan RAPBS & $-2,0$ & $-2,8$ & $-1,1$ \\
\hline 27 & Orang tua terlibat dalam pengawasan penggunaan dana BOS & $-1,9$ & $-2,8$ & $-1,2$ \\
\hline \multirow[t]{2}{*}{28} & Komite sekolah mengawasi penggunaan dana BOS & $-2,5$ & $-1,9$ & $-1,4$ \\
\hline & & 2,093 & 1,899 & $\begin{array}{c}- \\
1,099\end{array}$ \\
\hline
\end{tabular}

Sumber : data diolah Peneliti

Temuan hasil penelitian pada tahap pertama (Indonesia Barat) menunjukkan bahwa program BOS yang diharapkan oleh masyarakat (SD) adalah program yang harus dapat menyelesaikan masalah mereka mulai dari mereka berangkat sekolah, mendapat pelajaran di sekolah sampai dengan kembali lagi ke rumah $(-2,8)$. Tingginya angka putus sekolah jelas bukan karena biaya sekolah seperti biaya ekskul, LKS, dan kegiatan-kegiatan lain, namun karena tidak adanya uang untuk biaya transportasi anak menuju sekolah. Pengadaan dan penggunaan laboratorium IPA juga belum memadai(-2,7). Dari hasil wawancara pada level, ditemukan bahwa laboratorium IPA memang ada di sekolah namun sekolah tidak memanfaatkannya untuk praktek karena takut cepat rusak.Buku-buku sekolah elektronik memang dibagikan sekolah(-2,6), namun kualitasnya yang kurang memadai menyebabkan guru lebih senang menggunakan buku-buku dengan penerbit yang lebih terkenal karena banyak contoh-contoh soal sekaligus pembahasan disamping kualitas kertas dan lem kertas yang lebih kuat sehingga tidak mudah rusak. 
Sekolah dapat menyelenggarakan bimbingan kepada siswa-siswinya yang menghadapi berbagai masalah baik masalah pribadi yang mungkin dapat mengganggu konsentrasi belajar maupun masalah pelajaran sekolah hanyalah angan-angan semata (-2,5).Guru seperti karyawan pabrik yang ingin cepat-cepat pulang setelah jam kerjanya habis. Begitu bel pulang sekolah berbunyi banyak guru yang ikut bergegas pulang bersama siswa-siswinya.

Orang tua mendampingi sekolah dalam mengawasi penggunaan dana BOS sebagai komite sekolah $(-2,5)$ tidak pernah ideal pelaksanaannya. Menurut hasil wawancara, komite sekolah masih sangat jauh dari fungsi sesungguhnya. Komite sekolah hanya menjadi pihak yang harus menandatangani seluruh dokumen terkait penggunaan dana BOS dan bukan mengawasinya. Kesempatan untuk mengevaluasipun tidak diberikan. Memaksa untuk melakukan tugasnya dengan baik sama dengan membuka masalah baru antara sekolah dengan orang tua siswa sebagai komite sekolah yang berdampak buruk terhadap anak pengurus komite sekolah.

Indonesia Tengah, ditemukan kasus-kasus lemahnya daya tangkap siswa di daerah pedalaman karena lambatnya daerah menyerap teknologi akibat akses yang sangat sulit terjangkau. Masyarakat Indonesia Tengah membutuhkan guru yang berdedikasi tinggi, sehingga mau memberikan bimbingan lebih kepada siswa-siswi ini sehingga dapat mengejar ketertinggalannya dengan siswa-siswi yang ada di pusat-pusat kota besar. Sementara Program BOS ternyata belum mampu memotivasi guru untuk memberikan yang terbaik kepada anak didiknya. Pelajaran tambahan hanya diberikan kepada siswa yang akan menghadapi ujian nasional, padahal juklak memberikan bimbingan belajar untuk seluruh level kelas sebenarnya sudah ada pada program BOS. Lembar kerja siswa (LKS) sebagai sarana belajar yang cukup efektif, digunakan oleh beberapa sekolah sebagai alat pengumpul uang dengan menaikkan harganya.

Juklak pemberian dana transportasi bagi siswa-siswi dengan kondisi ekonomi yang sangat parah sudah ada, namun tidak tersalurkan. Banyak dari mereka akhirnya putus sekolah karena kondisi seperti ini berlangsung cukup lama dan mereka akhirnya putus asa menghadapinya. Pelajaran sekolah semakin banyak tertinggal, kondisi ekonomi terus melilit.Pilihan antara sekolah atau membantu orang tua mencari nafkah untuk menyambung hidup adalah bukan pilihan yang sulit bagi mereka. Teriakan perut dirinya dan jika mungkin adik-adiknya membuat mereka dapat dengan cepat memutuskan untuk keluar dari bangku sekolah.

Pada kota-kota besar seperti Jakarta, Bandung, Surabaya, dan Semarang ternyata memberikan hasil analisa GAP yang berbeda dalam mengukur kepuasan masyarakat terhadap program BOS. Ketidakpuasan yang paling besar adalah pada atribut 19, Guru membahas seluruh soal yang diberikan. Soal-soal memang diberikan melalui lembar kerja siswa (LKS) namun LKS tersebut jarang sekali dijamah guru. Idealnya LKS dikerjakan di rumah agar tidak banyak membuang waktu, kemudian dibahas di sekolah bersama guru. Namun pada kenyataannya guru biasanya mengerjakan pekerjaan lain namun tetap di dalam kelas, sedangkan siswa diinstruksikan untuk mengerjakan LKS sendiri.

Kondisi ekonomi yang timpang satu dengan lainnyadi kota besar seperti DKI Jakartajuga menjadi masalah, di satu sisi anak ingin bersekolah dan bermain dengan temannya, namun disisi lain lain mereka harus bekerja membantu orang tua memenuhi kebutuhan hidup. Maka tak heran jika DKI Jakarta sebagai kota besar mempunyai angka putus sekolah lebih dari 5\%. 
Gap pada kota besar $(-1,099)$ memang lebih kecil dibandingkan wilayahbarat $(-2,093)$ dan Tengah (-1,899). Pengawasan pelaksanaan program BOS di kota-kota besar bisa jadi lebih mudah dilakukan oleh pemerintah, sehingga penyimpangan yang terjadi juga lebih kecil. Komisi pemberantasan korupsi kerap membayang-bayangi mereka yang akan menyimpang. Sedangkan untuk daerah yang jauh dari kota dan cukup sulit untuk dijangkau oleh pengawas, memberi kesempatan kepada pihak pengemban amanat untuk mengalihkan ke kebutuhan yang lain yang bisa saja sebenarnya dibutuhkan oleh sekolah atau sebaliknya malah diselewengkan.

Hasil penelitian analisa gap kepuasan masyarakat terhadap program BOS pada level pendidikan SMP rerata wilayah Indonesia Barat menunjukkan bahwa seluruh atribut menghasilkan gap yang negatif. Orang tua siswa dan siswa itu sendiri mempunyai kepentingan yang ternyata jauh lebih tinggi dibandingkan realitas kinerja yang diberikan sekolah sebagai pengemban amanat program BOS. Ketidakpuasan masyarakat adalah pada guru kurang memberikan soal latihan di kelas sehingga siswa cenderung tidak terlatih dan tidak trampil. Guru di sekolah bukan seorang sarjana pendidikan sehingga mereka tidak memahami pendekatan proses pengajaran yang efektif, seperti bagaimana mengajar matematika yang menyenangkan bagi siswa. Guru tidak membahas seluruh soal latihan yang diberikan sehingga siswa tidak tahu jawaban yang benar, Program BOS belum sepenuhnya meringankan beban biaya sekolah. Siswa sulit berdiskusi materi pelajaran dengan gurunya di luar jam belajar dan pendalaman materi bagi siswa yang sangat lambat dalam menyerap materi menjadi atribut yang tidak memuaskan berikutnya.

Tabel 2.Analisa GAP Kepuasan Masyarakat (SMP)Terhadap Program BOS

\begin{tabular}{|c|c|c|c|c|}
\hline $\begin{array}{l}\text { No. } \\
\text { Atribut }\end{array}$ & Atribut Pelayanan & $\begin{array}{c}\text { GAP } \\
\text { IB }\end{array}$ & $\begin{array}{l}\text { GAP } \\
\text { IT }\end{array}$ & $\begin{array}{c}\text { GAP } \\
\text { KB }\end{array}$ \\
\hline 1 & Sirkulasi udara di ruang kelas baik & $-0,9$ & $-0,8$ & $-0,6$ \\
\hline 2 & Sekolah memiliki peralatan laboratorium IPA & $-1,9$ & $-2,2$ & $-0,2$ \\
\hline 3 & Sekolah mempunyai sarana olahraga & $-1,9$ & $-3,3$ & $-0,2$ \\
\hline 4 & Buku-buku pelajaran disediakan oleh sekolah & $-1,7$ & $-2,2$ & $-0,4$ \\
\hline 5 & Sanitary sekolah bersih & $-1,5$ & $-0,2$ & $-1,5$ \\
\hline 6 & Siswa berseragam dengan baik & $-0,7$ & $-0,5$ & 0 \\
\hline 7 & $\begin{array}{l}\text { Anda tidak dipungut uang pangkal/uang gedung oleh } \\
\text { sekolah }\end{array}$ & $-2,2$ & $-1,1$ & 0,8 \\
\hline 8 & Sekolah bebas dari iuran bulanan seperti SPP atau BP3 & $-2,2$ & 0 & 0 \\
\hline 9 & Sekolah ini bebas biaya ulangan tengah semester & $-2,9$ & $-1,2$ & 0 \\
\hline
\end{tabular}




\begin{tabular}{|c|c|c|c|c|}
\hline 10 & Siswa dibebaskan dari biaya ulangan akhir semester & $-2,3$ & $-1,5$ & 0,5 \\
\hline 11 & Buku-buku dipinjamkan oleh sekolah kepada siswanya & $-1,3$ & $-0,2$ & 0,5 \\
\hline 12 & $\begin{array}{l}\text { Program BOS meringankan beban biaya sekolah yang } \\
\text { harus Anda bayar }\end{array}$ & $-2,5$ & $-0,8$ & 0 \\
\hline 13 & $\begin{array}{l}\text { Pembebanan biaya dari sekolah tidak sama rata pada } \\
\text { setiap murid, namun melihat kemampuan keuangan } \\
\text { masing-masing }\end{array}$ & $-2,3$ & $-1,9$ & $-1,2$ \\
\hline 14 & $\begin{array}{l}\text { Kegiatan belajar mengajar sesuai dengan kalender } \\
\text { akademik }\end{array}$ & $-1,7$ & 0,1 & 0,4 \\
\hline 15 & $\begin{array}{l}\text { Sekolah tidak pernah memulangkan siswa lebih cepat } \\
\text { dari jadwalnya }\end{array}$ & $-1,6$ & $-0,8$ & $-0,2$ \\
\hline 16 & $\begin{array}{l}\text { Guru menguasi materi pelajaran yang diberikan kepada } \\
\text { siswa }\end{array}$ & $-2,0$ & $-0,4$ & $-1,0$ \\
\hline 17 & Guru mempunyai kemauan yang keras untuk mengajar & $-1,5$ & $-0,6$ & $-1,2$ \\
\hline 18 & Guru banyak memberikan soal-soal latihan & $-2,6$ & $-0,8$ & 0 \\
\hline 19 & Guru membahas seluruh soal yang diberikan & $-2,1$ & $-3,2$ & $-1,2$ \\
\hline 20 & Guru disekolah seorang sarjana pendidikan & $-2,6$ & $-0,4$ & $-0,8$ \\
\hline 21 & Guru mengenal dengan baik setiap siswa di kelas & $-2,1$ & $-0,8$ & $-1,4$ \\
\hline 22 & $\begin{array}{l}\text { Siswa dapat berdiskusi materi pelajaran dengan } \\
\text { gurunya di luar jam belajar pada hari sekolah }\end{array}$ & $-2,5$ & $-1,9$ & $-1,2$ \\
\hline 23 & Guru mengajar hingga siswa paham & $-1,8$ & $-1,8$ & $-0,9$ \\
\hline 24 & $\begin{array}{l}\text { Guru memberikan pendalaman materi kepada siswa } \\
\text { yang terlambat dalam menyerap materi }\end{array}$ & $-2,4$ & $-2,3$ & $-1,4$ \\
\hline 25 & $\begin{array}{l}\text { Program BOS meringankan beban biaya sekolah anak } \\
\text { Anda }\end{array}$ & $-2,6$ & $-1,7$ & 0 \\
\hline 26 & $\begin{array}{l}\text { Sebagian dana BOS digunakan untuk meringankan } \\
\text { biaya transportasi siswa ke sekolah }\end{array}$ & $-2,3$ & $-3,8$ & $-1,2$ \\
\hline 27 & Orang tua terlibat dalam penyusunan RAPBS & $-2,3$ & $-3,6$ & 0,1 \\
\hline
\end{tabular}




\begin{tabular}{|c|l|c|c|c|}
\hline 28 & $\begin{array}{l}\text { Orang tua terlibat dalam pengawasan penggunaan dana } \\
\text { BOS }\end{array}$ & $-2,1$ & $-3,0$ & 0,2 \\
\hline 29 & Komite sekolah mengawasi penggunaan dana BOS & $-2,2$ & $-2,8$ & $-0,8$ \\
\hline & RATA-RATA & $-2,05$ & $-1,50$ & $-0,49$ \\
\hline
\end{tabular}

Sumber : data diolah Peneliti

Wilayah Indonesia Tengah (Bali, NTB, NTT, Sulawesi, Kalimantan Selatan, Kalimantan Tengah, dan Kalimantan Timur) memberikan hasil yang agak berbeda dengan wilayah Indonesia Barat.Ternyata wilayah ini bersih dari pungutan SPP dan atau BP3 kepada siswa didiknya dan kegiatan belajar mengajar sesuai dengan kalender akademik pemerintah memberikan nilai positif (memuaskan). Sedangkan Ketidakpuasan tertinggi terhadap pelayanan sekolah adalah: Lagi-lagi masyarakat mengeluhkan tidak adanya subsidi pemerintah berupa dana transportasi siswa menuju sekolah, seperti terjadi pada masyarakat bagian barat Indonesia $(-3,8)$. Tidak ada sama sekali keterlibatan orang tua dalam penyusunan RAPBS $(-3,6)$. Padahal mereka berharap agar dapat duduk dalam pengurus Komite Sekolah dan memasukkan mata anggaran biaya transportasi bagi siswa tidak mampu dalam RAPBS. Pengawasan penggunaan dana BOS pun sulit dilakukan oleh pihak yang disebut sebagai Komite Sekolah. Masyarakat juga menyarankanbesarnya subsidi ini seharusnya tidak sama pada setiap wilayah, karena ketimpangan kondisi ekonomi antara di kota besar dan daerah pedalaman sangat tinggi.

Penelitian ini juga menemukan minimnya sarana olahraga standar (ketidaksesuaian ukuran, tidak ada sarana lempar lembing, tolak peluru dan lempar cakram) $(-3,3)$, padahal pelajaran olah raga adalah pelajaran favorit siswa karena pelajaran ini identik dengan bermain. Gap kepuasan masyarakat terhadap program BOS untuk empat kota besar pada level SMP sangat kecil yaitu $-0,49$, namun masih ada atribut yang tidak memuaskanyaitu guru membahas seluruh soal latihan yang diberikan $(-1,8)$, sanitary sekolah bersih $(-1,5)$, guru memberikan pendalaman materi bagi siswa yang terlambat menyerap materi pelajaran dan guru mengenal baik seluruh siswa dengan gap $(-1,4)$. Pembebanan biaya dari sekolah tidak sama rata pada setiap murid, namun melihat kemampuan keuangan masing-masing, Guru mempunyai kemauan yang keras untuk mengajar, Guru membahas seluruh soal yang diberikan, dan Sebagian dana BOS digunakan untuk meringankan biaya transportasi siswa ke sekolah $(-1,2)$.

Di kota-kota besar, pihak sekolah sangat takut memungut iuran dalam bentuk apapun kepada masyarakat, apalagi dengan judul uang gedung, uang pangkal, dan uang ulangan. Sarana dan prasarana sekolah sudah dibiayai pemerintah lewat dana RKB, selain masyarakat yang sudah pintar, maju dalam hal teknologi informasi yang akan dengan cepat melaporkan jika terdapat kecurangan dana BOS. Orang tua dalam wadah komite sekolah berperan aktif membantu sekolah dalam berbagai hal yang berkaitan dengan penghimpunan dana tambahan untuk mendukung proses belajar mengajar. Ditambah lagi inisiatif orang tua siswa memberikan kursus bimbingan belajar untuk anaknya, karena mereka merasa sekolah tidak maksimal proses belajar mengajarnya. 


\section{Technical Characteristics ( ${ }^{\text {rd }}$ Room)}

Adapun karakteristik teknispelayanan SD dan SMP penerima dana BOS adalah sebagai berikut: 1) Seluruh dana BOSdisalurkan ke seluruh sekolah; 2) Sistem pengawasan melekat; 3) Sistem pengelolaan terpadu antara sekolah, komite sekolah dan pemerintah; 4) Penyusunan, penggandaan \& penyebaran juklaksebagai pedoman pelaksanaan program BOS; 5) Sosialisasi program tentang mekanisme pelaksanaan; 6) Standarisasi sistem database; 7) Monitoring dan Evaluasi; 8) Peningkatan motivasi guru; 9) Pelayanan pengaduan masyarakat; 10) Juklak penggunaan dana BOS; 11) Juklak pengorganisasian BOS di sekolah; 12) Menggratiskan seluruh siswa miskin; 13) Meringankan beban biaya operasional sekolah di sekolah swasta; 14) Menambah fasilitas sekolah; 15) Berkurangnya angka putus sekolah; 16) Berkurangnya beban orang tua.

\section{Technical Correlations $\left(5^{\text {th }}\right.$ room)}

Technical correlation yang menunjukkan hubungan yang kuat antara karakteristik teknis berarti perbaikan pada item yang satu memberi dampak pada perbaikan item yang lain, bahkan bisa menyebabkan multiplier efect.

\section{Prioritas Redesain Program BOS $\left(6^{\text {th }}\right.$ room)}

Menurut hasil analisis dengan bagan house of quality, desain ulang terhadap karakteristik teknis program BOS untuk wilayah barat dan tengah Indonesia adalah sebagai berikut:

\section{Monitoring dan Evaluasi}

Karakteristik teknis yang pertama kali harus didesain ulang adalah Monitoring dan Evaluasi. Beberapa hal yang direkomendasikan terkait dengan monitoring dan evaluasi adalah:

a) Membentuk komite sekolah dari pegawai kelurahan dan atau kecamatan atau pemuka agama agar pengawasannya dapat maksimal dan tidak takut terjadi intervensi terhadap siswa.

b) Mengadakan pelatihan atau bimbingan teknis kepada para komite sekolah, sehingga mereka memahami juklak peruntukkan dana BOS

c) Mensahkan setiap rencana pengeluaran yang sesuai dengan juklak peruntukkan dana BOS dan tidak mau mensahkan laporan pertanggungjawaban jika transaksi tanpa pengesahan terlebih dahulu.

2. Sistem pengelolaan terpadu antara sekolah, komite sekolah, dan pemerintah, berarti membuat mekanisme bersama agar ketiga pihak ini transparan dalam menjalankan perannya masing-masing. Beberapa hal yang direkomendasikan terkait dengan sistem pengelolaan terpadu adalah:

a) Setelah menerima dana BOS informasikan waktu penerimaan, jumlah, dan rencana penggunaan dana tersebut kepada komite sekolah. 
b) Sebelum menggunakan uang untuk membayar bahan atau kegiatan operasional, sekolah harus meminta persetujuan terlebih dulu kepada komite sekolah.

c) Laporan pertanggungjawaban akhir yang diberikan ke pemerintah harus ditembuskan ke komite sekolah.

3. Motivasi guru dalam melayani siswa didik seharunya meningkat searah dengan peningkatan dana BOS yang diberikan pemerintah. Namun kenyataannya program BOS telah menyebabkan sekolah sibuk mengikuti mekanisme program. Karena harus membuat laporan pertanggungjawaban yang sangat merepotkan Bendahara BOS dan pejabat lainnya yang juga bertugas sebagai guru, tidak sempat lagi mencari terobosan baru dalam mengajar dengan cara yang menarik dan menyenangkan.

4. Beberapa hal yang direkomendasikan terkait dengan motivasi guru adalah:

a) Pekerjaan yang terkait dengan program BOS, seperti misalnya Bendahara BOS tidak boleh dipegang oleh seorang guru. Sekolah menunjuk pegawai tata usaha bagian keuangan untuk membuat laporan ini yang diawasi oleh Kepala Sekolah.

b) Sekolah menunjuk anggota komite sekolah sebagai bendahara BOS atau asisten bendahara BOS. Mekanismen ini sekaligus mengawasi penggunaan dana BOS

c) Menambah jam kerja guru di sekolah. Guru tidak pulang pada saat jam sekolah berakhir, namun tetap di sekolah hingga pukul 16.00 agar guru dapat melayani siswa didik yang bermasalah.

d) Pelatihan cara mengajar yang baik, menarik, dan menyenangkan harus dilakukan terutama untuk guru yang mengajar mata pelajaran yang sulit seperti Matematika, Bahasa Indonesia, dan IPA.

e) Memberikan reward khusus kepada guru favorit siswa, agar guru lebih termotivasi melayani siswa didiknya.

5. Juklak penggunaan dana BOS sangat jelas dan dengan mekanisme yang sangat teratur rapi. Namun karena keteraturannya ini terkesan sangat rumit. Rekomendasi: Membuat mekanisme yang lebih sederhana namun tetap terawasi, misalnya dengan membuat semacam kartu kredit, dimana didalamnya terdapat sejumlah dana BOS yang seharusnya dimiliki oleh sekolah. Kartu tersebut dapat dipakai untuk berbelanja atau diambil tunai yang besarnya mengikuti ketentuan batas per mata anggran. Jika satu mata anggaran sudah habis saldonya, maka pembelian baru untuk mata anggaran yang sama tidak akan pernah bisa dibayar oleh kartu tersebut.

6. Sistem pengawasan melekat oleh pemerintah berarti mengawasi penggunaan dana BOS seutuhnya agar program tepat sasaran. Rekomendasi:

a) Pemerintah menggali informasi tentang penduduk usia sekolah dasar di wilayahnya masing-masing. Apakah di wilayahnya semua penduduk usia sekolah bersekolah 
Hesti Maheswari

Luna Haningsih
Jurnal Manajemen Bisnis Indonesia

Vol. 2, Nomor 1, Oct 2014

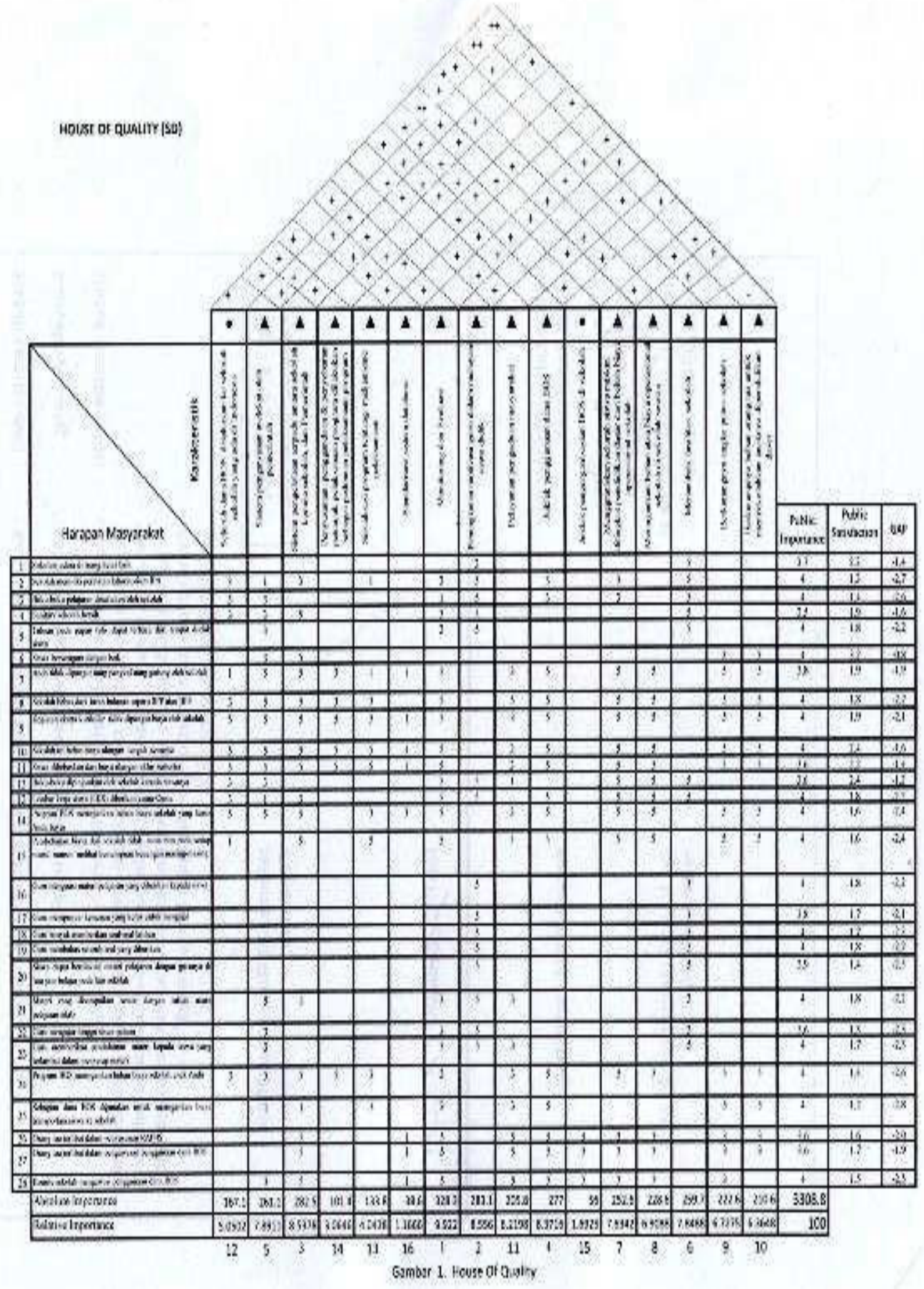


Hesti Maheswari

Luna Haningsih
Jurnal Manajemen Bisnis Indonesia

Vol. 2, Nomor 1, Oct 2014

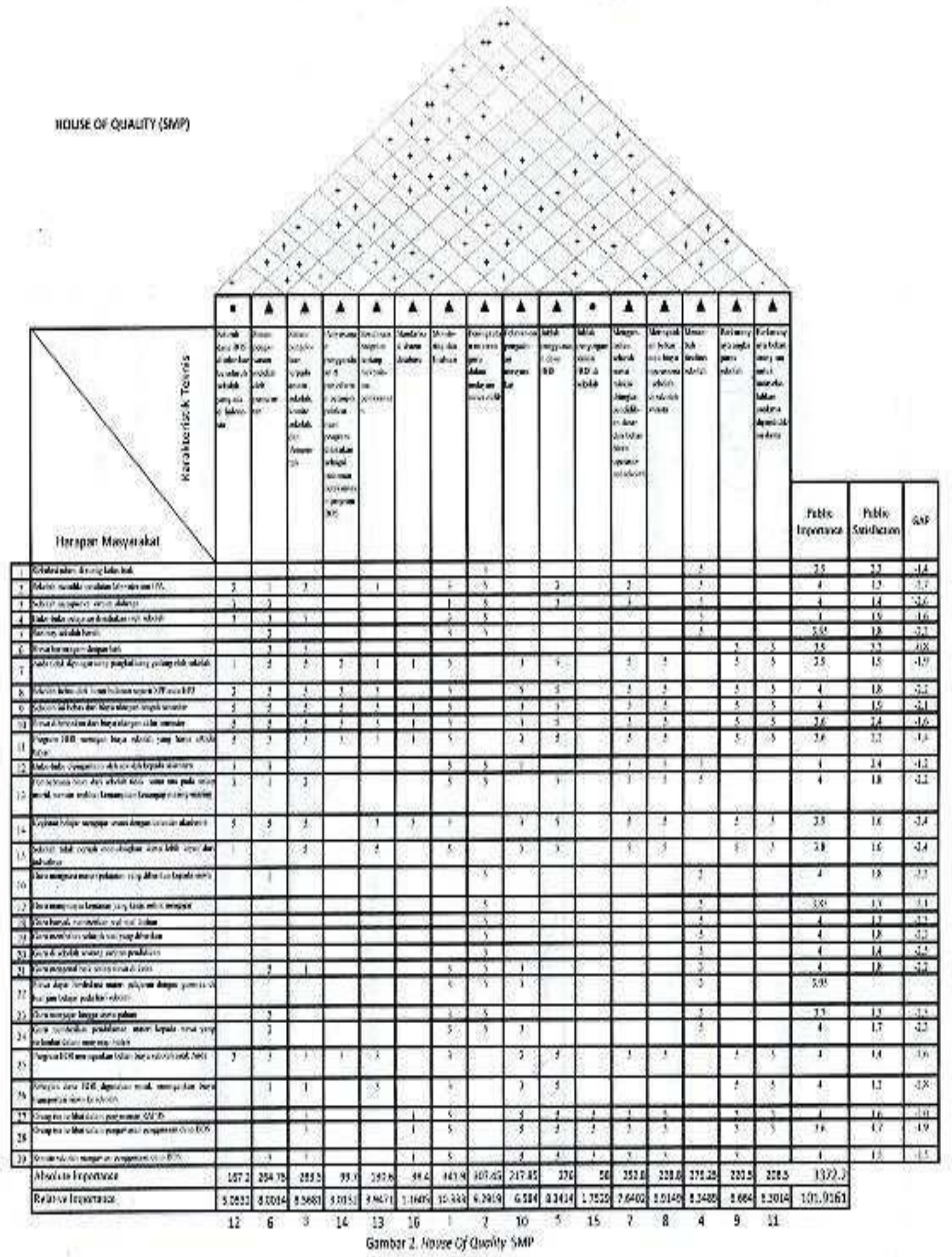


Hesti Maheswari

Luna Haningsih
Jurnal Manajemen Bisnis Indonesia

Vol. 2, Nomor 1, Oct 2014

b) Pemerintah mendeteksi kondisi ekonomi setiap keluarga yang mempunyai anak usia sekolah. Jika tidak mampu membiayai anaknya untuk berangkat kesekolah, maka harus diteruskan informasi ini ke sekolah terdekat dengan tempat tinggal calon siswa ini kemudian mewajibkan pihak sekolah menyisihkan dana BOS untuk biaya transportasi calon siswa ini.

7. Penambahan fasilitas sekolah, Sekolah harus memperhatikan fasilitas pendidikan diantaranya Hal yang direkomendasikan untuk penambahan fasilitas sekolah penggunaan dana RKB dan pemerintah dalam dinas pendidikan melalui pengawas sekolah menginventarisir fasilitas sekolah.

8. Menggratiskan seluruh siswa miskin di tingkat pendidikan dasar dari biaya operasional sekolah. Beberapa hal yang direkomendasikan adalah:

a) Memisahkan kondisi ekonomi setiap siswa dengan tingkat ketelitian tinggi

b) Membedakan proporsi subsidi untuk siswa yang satu dengan siswa lain tergantung pada kondisi ekonomi siswa tersebut.

c) Pemerintah membuat klasifikasi kondisi ekonomi siswa dan batasan subsidi sesuai dengan klasifikasi tersebut. Pemerintah harus tahu kelompok masyarakat yang harus diberikan subsidi penuh.

9. Meringankan beban atau biaya operasional sekolah di sekolah swasta. Pengawasan seharusnya lebih ketat kepada kelompok sekolah swasta yang diizinkan memungut biaya walaupun sekolah menerima dana BOS. Pastikan biaya yang dipungut benar-benar untuk pengembangan sekolah, penambahan fasilitas sekolah yang menyebabkan sekolah nyaman.

10. Untuk mengurangi angka putus sekolah Pemerintah harus meningkatkan keakuratan data usia sekolah hingga ke daerah pedalaman kemudian Pemerintah Pusat menginstruksikankepada Pemerintah Daerah yang kemudian diteruskan hingga lingkungan rukun warga dan rukun tetangga.

11. Berkurangnya beban orang tua untuk menyekolahkan anaknya di tingkat pendidikan dasar.

Beban orang tua dalam menyekolahkan anaknya akan berkurang jika semua pihak terkait dengan penyaluran dana BOS benar-benar menjalankan fungsinya dan tidak melakukan kecurangan.

12. Pengaduan masyarakat akibat penyelenggaraan sekolah gratis harus dibuka seluas-luasnya, agar pemerintah dapat mengevaluasi berjalannya proses pendidikan.

13. Seluruh dana BOS disalurkan ke seluruh sekolah yang ada di Indonesia. Pemerintah harus instrospeksi kembali tentang waktu penyalurannya yang sangat sering terlambat dan 
Hesti Maheswari

Luna Haningsih
Jurnal Manajemen Bisnis Indonesia

Vol. 2, Nomor 1, Oct 2014

14. menyebabkan mekanisme sekolah terkait pembayaran honor guru dan lain-lain menjadi kacau.

15. Hal yang perlu direkomendasikan terkait juklak pengorganisasian BOS di sekolah adalah tidak menunjuk seorang guru menjadi bendahara BOS. Lebih baik lagi jika bendahara BOS dipegang oleh anggota komite sekolah, agar pengawasan bisa lebih melekat.

16. Walapaun standarisasi sistem data basedterus dilakukan namun data di setiap sekolah belum seragam, terutama untuk sekolah-sekolah swasta kecil karena kurangnya tenaga profesional untuk melakukan tugas ini. Hal yang direkomendasikan untuk kondisi ini adalah pemerintah memberikan bimbingan teknis atau pelatihan terpadu.

\section{SIMPULAN}

\section{Simpulan}

a. Harapan masyarakatpada level pendidikan SD dan SMP terhadap Program BOS:

Terdapat 28 harapan masyarakat terhadap pelayanan pendidikan SD di sekolah-sekolah penerima program BOS. Sedangkan untuk level pendidikan SMP, ditemukan 29 tuntutan masyarakat terhadap pelayanan sekolah-sekolah peneriman Program BOS

b. Ketidakpuasan masyarakat terhadap program BOS dan menjadi harapan masyarakat adalah sebagai berikut:

- Harapan terbesar orang tua siswa dan siswa SDadalah sebagai berikut:1) Sebagian dana BOS dapat digunakan untuk biaya transportasi, 2) Sekolah memiliki dan memaksimalkan penggunaan Laboratorium IPA 3) Buku-buku berkualitas tersedia\& Program BOS dapat meringankan beban biaya sekolah , 4) Siswa dapat berdiskusi dengan gurunya di luar jam belajar, 5) Komite sekolah mengawasi penggunaan dana BOS, 6) Guru bersedia memberikan pendalaman materi kepada siswa yang lambat menyerap materi, 2) Lembar kerja siswa (LKS) diberikan, 3) Guru membahas seluruh soal yang diberikan.

- Harapan terbesar orang tua siswa dan siswa SMPadalah sebagai berikut: 1) Sekolah sepenuhnya membebaskan pungutan, 2) Program BOS meringankan biaya transportasi, 3) Guru banyak memberikan soal-soal latihan, 4) Guru membahas seluruh soal-soal, 5) Guru seorang sarjana pendidikan sehingga paham dalammendidik dan tahu cara yang tepat dalam mengajar. 6) Orang tua terlibat dalam penyusunan RAPBS, 7) Sekolah mempunyai sarana olahraga, 8) Orang tua terlibat aktif dalam pengawasan penggunaan dana BOS, 9) Sanitary sekolah bersih, 10) Guru memberikan pendalaman materi, 11) Guru mengenal baik seluruh siswa, 12) Pembebanan biaya dari sekolah tidak sama rata pada setiap murid, dan 13) Guru mempunyai kemauan yang keras untuk mengajar.

c. Karakteristik teknis program BOS yang harus didesain ulang dan yang harus dipertahankan terdiri atas: 1) Seluruh dana BOS disalurkan ke seluruh sekolah,2) Sistem pengawasan 
terpadu, 3) Sistem pengelolaan terpadu antara sekolah, komite sekolah dan pemerintah, 4) Penyusunan, penggandaan \& penyebaran petunjuk pelaksanaan program sebagai pedoman pelaksanaan program BOS, 5) Sosialisasi program tentang mekanisme pelaksanaan, 6) Standarisasi sistem database, 7) Monitoring dan Evaluasi, 8) Peningkatan motivasi guru 9) Pelayanan pengaduan masyarakat, 10) Juklak penggunaan dana BOS, 11) Juklak pengorganisasian BOS, 12) Menggratiskan seluruh siswa miskin, 13) Meringankan beban biaya operasional sekolah di sekolah swasta, 14) Penambahan fasilitas sekolah 15)Berkurangnya angka putus sekolah, 16) Berkurangnya beban orang tua

d. Desain ulang yang direkomendasikan untuk karakteristik teknis program BOS diuraikan pada akhir bab lima. Desain besar harus dilakukan pada lima karakteristik dengan angka absolute dan relative importance terbesar yaitu 1) Monitoring dan Evaluasi, 2) Peningkatan Motivasi guru dalam melayani siswa didik, 3) Sistem pengelolaan terpadu antara sekolah, komite sekolah, dan pemerintah, 4) Juklak penggunaan dana BOS, dan 5) Sistem pengawasan melekat oleh Pemerintah

\section{Saran}

a. Pemerintah dapat mewujudkan berkurangnya angka putus sekolah bersamaan dengan meningkatnya angka partsipasi murni anak usia sekolah bersekolah jika mekanisme penyaluran dana BOS tidak hanya digunakan untuk keperluan bahan-bahan habis pakai namun utnuk membantu biaya transportasi siswa menuju sekolah.

b. Pemerintah tidak boleh menyamaratakan kondisi ekonomi seluruh masyarakat begitu saja. Pemerintah harus mempunyai mekanisme pengawasan agar siswa yang cukup mampu mendapat porsi subsidi lebih kecil dibandingkan siswa yang tidak mampu sehingga sekolah dapat menyelenggarakan pendidikan berkualitas tanpa membebani siswa yang tidak mampu. 
Hesti Maheswari

Luna Haningsih
Jurnal Manajemen Bisnis Indonesia

Vol. 2, Nomor 1, Oct 2014

\section{REFERENSI}

Berita Antara, 7 Juli 2007

Dikti, 2010, Petunjuk Pelaksanaan BOS

Evans, Lindsay, 2013, Managing for Quality and Performance Excellence, Cengage Learning, South Western

Foster, 2013, Managing Quality Integrating The Suplly Chain, Pearson, England

Heizer, Jay. \& Barry. Render. (2012). Manajemen Operasi, Edisi tujuh, Jakarta : Salemba Empat.

SMERU, 2013,

Suara Pembaharuan, Februari 2009

UU Pendidikan Dasar, 2004 No. 20 pasal 34 ayat 2 dan 3

Zikmund, 2013, Babin, Carr, Business Reseacrh Methods, Cengage Learning, South Western

\section{BIODATA PENULIS}

Hesti Maheswari, Sarjana Ekonomi, Jurusan Manajemen Universitas Jenderal Soedirman, lulus tahun 1994. Memperoleh gelar Magister Sains Program Pasca Sarjana Magister Ilmu Manajmen Universitas Padjajaran, lulus tahun 2002, Saat ini menjadi Dosen di Fakultas Ekonomi dan Bisnis Universitas Mercu Buana.

Luna Haningsih, Sarjana Ekonomi, Jurusan Manajemen Universitas Gadjah Mada, lulus tahun 1991. Memperoleh gelar Magister Sains Program Pasca Sarjana Magister Ilmu Manajmen Universitas Indonesia, lulus tahun 2000, Saat ini menjadi Dosen di Fakultas Ekonomi dan Bisnis Universitas Mercu Buana.

\section{BIODATA PENULIS}

Hesti Maheswari, Sarjana Ekonomi, Jurusan Manajemen Universitas Jenderal Soedirman, lulus tahun 1994. Memperoleh gelar Magister Sains Program Pasca Sarjana Magister Ilmu Manajmen Universitas Padjajaran, lulus tahun 2002, Saat ini menjadi Dosen di Fakultas Ekonomi dan Bisnis Universitas Mercu Buana.

Luna Haningsih, Sarjana Ekonomi, Jurusan Manajemen Universitas Gadjah Mada, lulus tahun 1991. Memperoleh gelar Magister Sains Program Pasca Sarjana Magister Ilmu Manajmen Universitas Indonesia, lulus tahun 2000, Saat ini menjadi Dosen di Fakultas Ekonomi dan Bisnis Universitas Mercu Buana. 